\title{
FAREWELL TO THE RULE OF RECOGNITION?
}

\author{
Giorgio PINO*
}

\section{Resumen:}

En este artículo se argumenta que la regla de reconocimiento, tal como fuera concebida por Hart, es o bien un concepto redundante - y en consecuencia inútil- o un concepto limitado en su poder explicativo. En cualquier caso, se trata de un concepto cuyo alcance es, frente a los sistemas jurídicos contemporáneos, mucho más estrecho de lo que Hart pudo imaginar. De igual modo se argumenta que la regla de reconocimiento, en alguna de sus posibles (y plausibles) reformulaciones, puede tener a pesar de todo un papel significativo y no redundante, pero solamente si se emplea en un sentido radicalmente distinto al que propuso Hart o que se propone en buena parte de la literatura positivista posthartiana.

\section{Palabras clave:}

Regla de reconocimiento, sistema jurídico, validez jurídica, aplicabilidad, H. L. A. Hart.

\section{Abstract:}

I will argue that the rule of recognition, as it has been conceived by Hart, is either a redundant, and hence mostly useless, concept, or a concept with limited explanatory potential -in either case, at best a concept whose scope is, in contemporary legal systems, much narrower than Hart envis-

* Associate Professor of Legal Philosophy, University of Palermo giorgio.pino @unipa.it, www.unipa.it/gpino. 


\section{GIORGIO PINO}

aged. I will also argue that the rule of recognition, in one of its possible (and plausible) reformulations, can nevertheless play a significant, non-redundant role, but only if employed in a rather different way than the one proposed by Hart, as well as by much of post-Hartian positivist literature.

\section{Keywords:}

Rule of Recognition, Legal System, Legal Validity, Applicability, H. L. A. Hart. 
FAREWELL TO THE RULE OF RECOGNITION?

Summary: I. Trouble in Paradise. II. Hart's Account of the Rule of Recognition. III. What kind of Rule is the Rule of Recognition. IV. The Rule of Recognition Revisited. V. Bibliography.

\section{TROUBle IN PARADISE}

The concept of a rule of recognition - the ultimate rule establishing the criteria of validity of the other rules of a given legal system- is notoriously one the most long-standing and far-reaching contributions of H. L. A. Hart to legal theory. ${ }^{1}$ It has attracted countless sympathetic attempts of refinement and development, as much as harsh criticism. At the same time, while Hart envisaged for the rule of recognition a paramount clarifying role for legal theory and jurisprudence, ${ }^{2}$ his own exposition of the doctrine of the rule of recognition is famously affected by some ambiguities and obscurities.

1 See M. Kramer, Where Law and Morality Meet, 104 (the idea of a rule of recognition is "[o]ne of Hart's greatest contributions to the philosophy of law"); A. Marmor, Philosophy of Law, 50 ("No other idea is more closely associated with Hart's theory of law than the idea that legality is constituted by social rules of recognition").

Jules Coleman probably overstates the point though when he says that commitment to the rule of recognition, along with the separability thesis, is a defining feature of legal positivism (see 'Authority and Reason', 287, $316 \mathrm{fn} 5$ ). On the one hand, if the rule of recognition is understood in a strictly Hartian sense, then as a matter of fact it is not true that all legal positivists are committed to such a thesis (one hardly needs to mention Austin, Kelsen, and Ross to this effect). On the other hand, if the rule of recognition is understood in a very broad and very weak sense, as a criterion whatsoever to delimitate the law, then not only legal positivism but virtually every kind of legal theory uses or presupposes a rule of recognition of some kind (some criterion to distinguish the law, as the subject matter of legal theory, from other phenomena such as religion, sheer violence, the game of chess, etc.). Accordingly, Scott Shapiro rightly notes, for example, that in a sufficiently weak sense also 'Law-as-Integrity' amounts to a rule of recognition: see 'What Is the Rule of Recognition (and Does It Exists)?', 267.

2 According to Hart, the existence of a socially practised rule of recognition provides 'the foundations of a legal system' (The Concept of Law, 100). Moreover, Hart repeatedly claims, paraphrasing Austin, that the union of primary and secondary rules (among which there is the rule of recognition) is 'the key to the science of jurisprudence': see The Concept of Law, 81; 'Positivism and the Separation of Law and Morals', 59. 
In this essay I will argue that the rule of recognition, as it has been conceived by Hart and by much of post-Hartian legal theory, is either a redundant, and hence mostly useless, concept, or a concept with limited explanatory potential -in either case, at best a concept whose scope is, in contemporary legal systems, much narrower than Hart envisaged. I will also argue that the rule of recognition, in one of its possible (and plausible) reformulations, can nevertheless play a significant, non-redundant role, but only if employed in a rather different way than the one proposed by Hart (as well as by much of post-Hartian positivist literature). So, at the end of the day the answer to the question posed by the title of this essay will be a qualified 'No' - it is not necessary to give up entirely the concept of rule of recognition, but only insofar as we are willing to mould the concept of rule of recognition in a different way, assigning it a slightly different job than the one that seems to appear from The Concept of Law, as well as from much of post-Hartian literature. (I believe nevertheless that such a proposal turns out to be not only compatible, but also deeply coherent with the overall positivist project underwritten by Hart).

The argument proceeds as follows. I will first (§ 2) summarize Hart's main arguments on the rule of recognition, also pointing at some possible developments to which Hart's original statement of the relevant concept is reasonably amenable. Then ( $(3)$ I will move on to consider the main interpretations, or reformulations, that the concept of rule of recognition has undergone in post-Hartian legal theory, briefly testing them in light of their theoretical pros and cons. Finally $(\S 4)$, I will try to offer an alternative reconstruction of the concept of rule of recognition, trying to show that this concept can play an important, non redundant role, provided we accept that it is not the role envisaged by Hart.

A few caveats are in place here. First, my argument will be at first exegetical in character (I will try to be as faithful 
as possible to Hart's rendering of the rule of recognition), but my main aim in this paper is not just to provide a trustful interpretation of Hart's thought; rather, what I aim to is to carve out a useful and significant concept in its own right - I want to explore the possibility that the rule of recognition be rescued from the charge of redundancy (a charge that I am by no means not alone in levelling). ${ }^{3}$ Second, this essay will be firmly grounded in the legal positivist theoretical field, or so its author hopes. In other words, my theoretical objections to the rule of recognition will not be the upshot of a Dworkinian, 'interpretivist', theoretical stance, ${ }^{4}$ which it is not my concern neither to endorse nor to critically evaluate here. Suffice it to say that I am here assuming the general soundness and defensibility of a positivist, Hartian theoretical stance, and I am exploring the possibility of improving it further.

\section{HaRt's Account of the Rule of Recognition}

Briefly, Hart's own account of the rule of recognition runs as follows. ${ }^{5}$

Every modern, developed legal system includes a peculiar 'secondary' rule - the rule of recognition - whose function is to provide authoritative criteria according to which primary rules of obligation can qualify as 'valid'. The rule of recognition can perform such a task in many possible ways -typically, by pointing to one or more features possession of which makes of a rule a rule of law, a valid legal rule.

3 See, among others, the authors quotes infra, fn 59.

4 For Dworkin's multifaceted criticism of the rule of recognition (that are part and parcel of his broader rejection of legal positivism, both in Hartian guise and otherwise), see 'The Model of Rules I' and Law's Empire. On 'interpretivist' theories of law see N. Stavropulos, 'Interpretivist Theories of Law'.

5 The main source is obviously The Concept of Law, 91-123. Hart provides other insights on the rule of recognition (even if he does not always refer to it exactly in this way), at least in 'Positivism and the Separation of Law and Morals'; 'Lon L. Fuller: The Morality of Law'; 'Kelsen's Doctrine of the Unity of Law'; 'Postscript'. A good synthesis (but limited to The Concept of Law and the 'Postscript') is in J. Dickson, 'Is the Rule of Recognition Really a Conventional Rule?'. 
The rule identified following the criteria stated by the rule of recognition can then be said to be part of the legal system -indeed, the idea itself of a legal system requires the existence of a unifying rule of recognition. 6 The criteria of validity encapsulated in the rule of recognition can take a variety of forms: reference to a certain text, or to a procedure ("legislative enactment") are the most common hypotheses. ${ }^{7}$ If in the relevant legal system law-making power is itself regulated by (secondary) rules — rules of change- then the rule of recognition of that system will 'necessarily' include reference to the operation of such rules. ${ }^{8}$ When there are multiple sources of the law, the rule of recognition normally provides also some criteria for their hierarchical ordering. ${ }^{9}$ As a (ultimate) criterion of validity, the rule of recognition is not itself valid; indeed, it is neither valid nor invalid, since there is no further criterion that can be used to assess its validity. ${ }^{10}$ Neither the rule of recognition is explicitly stated, at least "for the most part":11 its existence has to be inferred from the actual law-ascertaining practices of the officials; in other words, "its existence is a matter of fact". ${ }^{12}$ A rule of recognition exists if there is a convergent practice among officials of treating as valid law what is validated by the rule of recognition (the relevant practice qualifying as an 'acceptance from the internal point of view'). ${ }^{13}$

Hart's account of the rule of recognition has spurred a huge and manifold debate. The main theoretical enquiries prompted by Hart's analysis of the rule of recognition have largely focused $i$ ) on the existence conditions of the rule of recognition; ii) on the possible content of the rule of recog-

6 The Concept of Law, 95, 116, 148.

7 Ibidem, 95, 100, 101

8 Ibidem, 96.

9 Ibidem, 95, 101, 106.

10 Ibidem, 109.

11 Ibidem, 101, 102.

12 Ibidem, 110; see also 108, 116.

13 Ibidem, 102, 116, 117. 
nition, i.e. the problem of logical or conceptual constraints on the criteria of validity that can possibly be enshrined in the rule of recognition; iii) on the function of the rule of recognition.

Legal theorists arguing problem i) are engaged in trying to figure out what kind of state of affairs must be obtained in order to bring a rule of recognition into existence, elaborating on Hart's scattered remarks on the convergent behaviour of officials sharing an internal point of view: and much of the discussion has revolved around the theoretical viability of understanding the relevant practice as a 'convention' -an idea that Hart himself eventually endorsed, even if in somewhat mild terms. ${ }^{14}$ Debate on ii) aims at establishing if there are conceptual limits to what can be included by a rule of recognition among the criteria of legality: those who deny that there are such conceptual constraints, and especially that such constraints do not rule out morality from acting as a criterion of legal validity, have come to be known as 'inclusive' or 'soft' positivists, or 'incorporationists'. Those who argue that the rule of recognition cannot contemplate reference to morality as a criterion of legal validity, for conceptual reasons related to the concept of authority and to the function of guidance of conduct that is said to be typically performed by the law, are said to adhere to 'exclusive' or 'hard' positivism.15 A third strand, lastly, denies that the rule of recognition should make reference to contested moral principles, and this is asserted on ethical,

14 See 'Postscript', 255, 267. Conventionalist accounts of the rule of recognition are elaborated by G. Postema, 'Coordination and Convention at the Foundations of Law'; E. Lagerspetz, The Opposite Mirrors; J. Coleman, The Practice of Principle, esp. ch 7; A. Marmor, Positive Law and Objective Values, chs 1 and 2; S. Shapiro, 'Law, Plans, and Practical Reason'. For a critical assessment, see L. Green, The Authority of the State, ch 4, and 'Positivism and Conventionalism'; B. Celano, 'La regola di riconoscimento è una convenzione?'; J. Dickson, 'Is the Rule of Recognition Really a Conventional Rule?'; A. Schiavello, Perché obbedire al diritto?

15 On the inclusivist side, see e.g. W. Waluchow, Inclusive Legal Positivism; J. Coleman, The Practice of Principle; M. Kramer, Where Law and Morality Meet. On the exclusivist side, see e.g. J. Raz, 'Legal Positivism and the Sources of Law' and 'Authority, Law, and Morality'; S. Shapiro, 'On Hart's Way Out'. 
not conceptual grounds - this has come to be known as 'normative' positivism. ${ }^{16}$

In the following of this essay, I will not touch upon matters under i) and ii). By contrast, in this essay I will deal with iii) - a comparatively less explored issue, that nevertheless has also attracted a fair amount of theoretical interest in its own right. So in the following I will try to make sense of the issue of the function of the rule of recognition: what is it there for, what kind of (theoretical, conceptual, or otherwise) role does it perform in a legal system, and also in a legal-theoretical account of a legal system?

Before turning to this, however, I will point to some possible refinements that Hart's account of the rule of recognition seems amenable to, and that will be somewhat useful also for the rest of the present discussion.

First, while Hart repeatedly asserts that the (secondary) rule of recognition provides the test of validity for primary rules of obligation, it is common ground in positivist, Hartian legal theory that the rule of recognition validates all the other rules of the system, primary and secondary alike. ${ }^{17}$

Second, Hart usually talks of one rule of recognition, but occasionally also of rules of recognition; 18 so how many rules of recognition are to be found in a legal system? The answer seems to be that while in each legal system there is just one (ultimate) rule of recognition, this is bound to be very complex and hierarchically structured, and it is also possible that different kind of officials in the legal system follow different or partly different rules of recognition due to their different institutional roles. ${ }^{19}$ Lastly, it is also possible that the officials of the legal system do not follow exactly the same rule of recognition, not because of their different in-

\footnotetext{
16 See N. MacCormick, 'A Moralistic Case for A-Moralistic Law'; J. Waldron, 'Normative (or Ethical) Positivism'.

17 See e.g. J. Raz, 'The Identity of Legal Systems', 91.

18 See The Concept of Law, 102, 104, where Hart refers to rules (plural) of recognition.

19 J. Raz, The Concept of a Legal System, 200; P.M.S. Hacker, 'Hart's Philosophy
} of Law', 24. 
stitutional positions, but because they disagree in identifying the relevant rule of recognition. While radical disagreement between officials as to the rule of recognition endangers the unity - and the working itself - of the legal system, with consequences that can range from extreme unpredictability in judicial decisions to revolution and civil war, a degree of marginal disagreement, or disagreement at lower levels in the chain of validity, can be easily accommodated in the conceptual framework of the rule of recognition; this is so because - as Hart explicitly admits - the rule of recognition partakes of the 'open texture' that affects every rule and so it cannot be expected to provide a determinate answer to all cases. ${ }^{20}$ What degree of indeterminacy is tolerable in the rule of recognition, or to put it differently, what degree of overlap between the different rules of recognition is needed, is a question that is not possible to answer in abstract terms.

Third, does the rule of recognition compound all the criteria of validity for one legal system (regulates the validity of all the kind of legal norms that belong to the system), or is it an ultimate test of validity? Hart actually defines the rule of recognition exactly as the ultimate criterion of validity, meaning that the rule of recognition is not in turn validated by other rules. ${ }^{21}$ Moreover, the rule of recognition needs not specify the criteria of validity of all the norms of the system: the criteria of validity for certain kind of norms (call them N2) can be established not by the rule of recognition but by some other norm N1, whose validity is established by the rule of recognition (and so $\mathrm{N} 2$ is directly validated by $\mathrm{N} 1$, and indirectly validated by the rule of recognition): so there can be derivative criteria of validity, as it were, along with the ultimate ones provided by the rule of recognition. ${ }^{22}$

20 The Concept of Law, 147-154. The issues discussed in this paragraph are further explored by M. Kramer, Where Law and Morality Meet, 105-110.

21 The Concept of Law, 105-106.

22 J. Raz, 'The Identity of Legal Systems', 95; K. Greenawalt, 'The Rule of Recognition and the Constitution', 5-6; M. Kramer, Where Law and Morality Meet, 110; L. 
Fourth, in The Concept of Law Hart seems to be committed to the view that the rule of recognition instantiates 'pedigree' only criteria of validity, meaning that validity is to be assessed only by reference to formal, factual criteria. ${ }^{23}$ In this way, the rule of recognition can establish the validity of legal sources only, and not the validity of legal norms as well -a norm being the meaning, the content of a legal source: norms are what the sources say, or are taken to say by means of interpretation. A possible explanation for this limitation on the criteria of validity in the rule of recognition is that Hart's original account was probably influenced by his semi-formalist theory of legal interpretation, ${ }^{24}$ according to which sources of law are capable of carrying a core of settled, undisputable meaning, along with an area of penumbra where there is some uncertainty and the interpreter is called upon to use some degree of interpretive discretion. Be that as it may, the source-based account of validity has notoriously been the main ground for Dworkin's original attack ${ }^{25}$ on Hartian positivism, for its alleged incapability of explaining the use of legal principles in adjudication. Responding to Dworkin, in the 'Postscript' to the second edition of The Concept of Law, Hart eventually admitted that reference to source-based only criteria of validity was just a matter of emphasis: conceptually, his model is intended to accommodate also material, substantive criteria of validity as opposed to only formal ones. ${ }^{26}$

Alexander and F. Schauer, 'Rules of Recognition, Constitutional Controversies, and the Dizzying Dependence of Law on Acceptance', 177.

23 This emerges from the repeated references Hart makes to 'enactment' and similar concepts as the main test of validity; see The Concept of Law, 94, 95 ("fact of their having been enacted"), 96, 100, 101, 148, 209 ("valid by the formal tests..."). Probably the only counter-example is at 204 ("in some systems, as in the United States, the ultimate criteria of validity explicitly incorporate principles of justice or substantive moral values").

24 This is suggested by E. Diciotti, 'Regola di riconoscimento e concezione retorica del diritto', 13.

25 See R. Dworkin, 'The Model of Rules I'.

26 See 'Postscript', 250, 264-266. Hart anticipated this point also in 'Lon L. Fuller: The Morality of Law', 361. 


\section{What Kind of Rule is the Rule of Recognition?}

I assume that the picture drawn in last section (Hart's own account of the rule of recognition, plus a few minor amendments, or clarifications) compounds the standard view on the rule of recognition in contemporary positivist literature. ${ }^{27}$

Given this background, I now turn to the central problem for this essay, that of the nature and function of the rule of recognition. Here there is considerably less agreement between jurisprudents, and on close inspection Hart's account of the rule of recognition reveals many puzzling features. (As I have made it clear earlier, I am here broadly endorsing the Hartian project, and so I am assuming that something like the rule of recognition exists, or better that something like the rule of recognition is a good conceptual tool in order to attain a satisfying understanding of law and legal systems. So, the puzzles I have in mind are internal, so to say, to the Hartian account of rule of recognition. It is of course possible to adopt an external stance towards Hart's jurisprudence, and hence to deny that anything like the rule of recognition can help us in the way of a sensible understanding of the law; I am not exploring here this line of argument).

First and foremost, it is not entirely clear what kind of rule the rule of recognition is meant to be. Hart famously distinguishes between primary and secondary rules, and he plainly says that the rule of recognition is a secondary rule. The problem is that 1) the distinction itself between primary and secondary rules is far from clear, and moreover 2) the rule of recognition in Hart's characterization does not seem to square well with either kind of rules.

1) As far as the distinction between primary and secondary rules is concerned, many critics have remarked that

27 To be sure, exclusive legal positivist are likely to deny the last point made in the previous section, i.e. the possibility of substantive, as opposed to formal and factual, criteria of legal validity. But I don't think they would deny that Hart ended with admitting such a possibility. 
Hart uses the distinction in a number of different, and sometimes incompatible, ways. ${ }^{28}$ For instance, Hart on the one hand says that primary rules are duty-imposing rules, rules of obligation, while secondary rules are power-conferring rules, they provide facilities (which would make the relevant distinction deontic in character);29 on the other hand Hart also says that primary rules are rules aimed at guiding conduct, while secondary rules are rules about (other) rules (which would make the relevant distinction one of content). ${ }^{30}$ Such two distinctions are not equivalent, because a rule can of course impose a duty to apply other rules: as such, it would be a primary rule on one interpretation (because it is duty-imposing), and a secondary rule on another (because it is a rule about other rules).

2) Hart explicitly defines the rule of recognition as a secondary rule. As such, it should be regarded as a power-conferring rule. At the same time, however, Hart says that the rule of recognition states the criteria according to which validity of other rules is to be assessed. As such, the rule of recognition looks like a test, or a list of features possession of which grants validity. Now, the obvious problem is that a list or a test do not confer any power whatsoever. It is like a definition, and a definition is hardly a norm, let alone a power- conferring norm.

Against this problematic background, let's take a quick look at the more recurrent ways of conceiving of the rule of recognition in post-Hartian legal theory. (To be sure, for each of the following instances it is not always clear if it is best understood as an interpretation of Hart's thought, or rather as a reformulation of the concept itself of the rule of recognition, leaving aside the question if Hart would have endorsed such reformulation.) This will enable us to grasp at least what the rule of recognition plausibly cannot be.

28 L. Cohen, 'Critical Notice'; N. Bobbio, 'Norme primarie e norme secondarie'; J. Raz, 'The Functions of Law'; N. MacCormick, H. L. A. Hart, 106; W. Waluchow, Inclusive Legal Positivism, 75; L. Green, 'The Concept of Law Revisited', 1699.

29 The Concept of Law, 81, 96, 97.

30 Ibidem, 81, 94. 
(a) The rule of recognition as a duty-imposing rule. ${ }^{31}$ According to this interpretation, against Hart's many explicit statements that the rule of recognition is a secondary rule (and so either a power-conferring rule, or a rule about other rules, or both), the rule of recognition is in fact a primary, duty-imposing rule: it imposes upon officials a duty to apply (valid) law; as a consequence, the rule of recognition imposes a duty whose content is the exercise of a power (judicial power). This interpretation is substantiated in a number of ways. For instance, it is said that since Hart acknowledges only two kinds of rules (duty-imposing and power-conferring), and since the rule of recognition is not power-conferring, then it must be a duty-imposing rule. ${ }^{32}$ Another argument is that Hart explicitly provides an analysis of social rules as sources of obligations (the so-called 'practice theory of rules') 33 - while he does not provide an equally accurate analysis of the acceptance/existence of power-conferring rules; and since the rule of recognition exists only as a social rule, then it must be a duty-imposing rule. ${ }^{34}$ Moreover, the duty-imposing character of the rule of recognition is regarded as the key (or at lest the first step) towards explaining law's normativity. ${ }^{35}$

31 P. M. S. Hacker, 'Hart's Philosophy of Law', 24; N. MacCormick, H. L. A. Hart, ch 9; L. Green, The Authority of the State, 118; J. Coleman, The Practice of Principle, 84 ff; S. Shapiro, 'What Is the Rule of Recognition (and Does It Exists)?', 240, and Legality, 85.

32 See S. Shapiro, 'What Is the Rule of Recognition (and Does It Exists)?', 239. Such an argument a contrario is somewhat weak, because Hart does not intend the dichotomy duty-imposing/power-conferring rule to be exhaustive (The Concept of Law, 32; 'Lon L. Fuller: The Morality of Law', 358). But it is true nonetheless that it would appear strange if Hart would have left just the rule of recognition in the terra incognita of the unexplored kind of rules different from the duty-imposing and power-conferring ones.

33 This label is due to J. Raz, Practical Reason and Norms, 49-58. Hart later endorsed this definition: see 'Postscript', 254-259.

34 J. Raz, 'The Identity of Legal Systems', 92-93; S. Perry, 'Where Have All the Powers Gone? Hartian Rules of Recognition, Noncognitivism, and the Constitutional and Jurisprudential Foundations of Law', 305-308.

35 For a detailed analysis of this, see J. Coleman, The Practice of Principle, chs. 6-10. 
This approach is tempting, and indeed in the next section I will defend a version of it. But as it stands it suffers from some weaknesses. For instance, it does not explain why sometimes judges have a duty to apply non-valid law, or conversely even a duty not to apply valid law (I will return on this point shortly). Moreover, under this approach, if taken at face value, the rule of recognition imposes a duty to apply valid law, but does not point to any direction to ascertain what counts as valid law. So either the legal system provides elsewhere some independent criteria of validity, ${ }^{36}$ or the rule of recognition must be supplemented with in-built, as it were, criteria of validity. To this last possibility I now turn. ${ }^{37}$

(b) The rule of recognition as a duty-imposing rule and a list of criteria of validity. ${ }^{38}$ Under this reading, the rule of recognition both includes a list of features possession of which renders a norm a valid legal norm, and states a duty for law applying officials to apply valid rules in complying with their institutional roles.

While this interpretation escapes some of the difficulties affecting interpretation (a), it is still the case that sometimes judges have a (legal) duty to apply non-valid law, as well as they can have a (legal) duty not to apply valid law. ${ }^{39}$ This is so, because judges may quite often have a legal duty to apply norms that are not valid in any plausible meaning:

36 This seems to be MacCormick's position: see H. L. A. Hart, 115.

37 A third possibility is utterly rule-skeptic, or legal-realistic: valid law is whatever judges feel they are compelled to apply. On this reading, the rule of recognition would not properly exist, or either it would be indistinguishable from rules of adjudication (once judges are in place, whatever they do is law).

38 J. Raz, 'The Identity of Legal Systems', 93; M. Atienza, J. Ruiz Manero, A Theory of Legal Sentences, ch 5; S. Perry, 'Where Have All the Powers Gone? Hartian Rules of Recognition, Noncognitivism, and the Constitutional and Jurisprudential Foundations of Law', 305-306.

39 W. Waluchow, Inclusive Legal Positivism, 65-66, 77 ("not all the judges must (legally) apply is law validated by a rule of recognition; and [...] not all laws validate by a rule of recognition must be applied by judges"); for some examples, see J. J. Moreso, Legal Indeterminacy and Constitutional Interpretation, 108 ff; G. Pino, 'Norme e gerarchie normative', 279-288, 294-299, and 'La aplicabilidad de la norms jurídicas'. 
foreign laws, moral norms or considerations, 40 invalid laws (since a lower court may well have the legal duty to apply unconstitutional norms whose invalidity has not been ruled by a Constitutional Court) ${ }^{41}$ or even repealed statutes. Sometimes, law-applying institutions do not have exactly an explicitly stated legal duty to this effect, but still their resorting to extra-legal or extra-systemic standards is considered legally appropriate and acceptable. ${ }^{42}$ As a consequence, it remains to be explained how is it possible that the same rule states criteria of validity, imposes a duty to apply valid law, and authorizes departure from valid law at the same time.

Moreover, conflating validity and duty to apply (= bindingness) takes us right to a Kelsenian conception of validity as binding force, a conception whose compatibility with a coherent positivist approach is questionable to say the least (since it is hard to reconcile the positivist thesis that law is a fact, with the claim that this 'fact' has binding force), ${ }^{43}$ and that Hart for one surely did not share. ${ }^{44}$

(c) The rule of recognition as a closure rule. ${ }^{45}$ One possible additional function of the rule of recognition, often asserted

40 I am emphatically not claiming that a moral norm cannot at the same time be also a legal norm: rather, I am here referring to a different phenomenon, when the law does not refer to a specific moral principle, but rather explicitly defers to the judge the use of a moral assessment of some aspects of the case at hand. Here I have in mind what in many Continental, civil law systems is known as 'giudizio di equità'.

41 For a subtle but interesting discussion of this problem, see the exchange between K.E. Himma, 'Making Sense of Constitutional Disagreement: Legal Positivism, the Bill of Rights, and the Conventional Rule of Recognition in the United States', and M. Kramer, Where Law and Morality Meet, 115-140; see also W. Waluchow, 'Four Concepts of Validity'.

42 This is the case of the recent use of foreign authorities by the US Supreme Court; see Roper v. Simmons 125 S. Ct. 1183 (2005); Lawrence v. Texas, 123 S. Ct. 2472, 2483 (2003).

43 For a classic discussion of this, see A. Ross, 'Validity and the Conflict between Legal Positivism and Natural Law'.

44 See J. Raz, 'The Purity of the Pure Theory', 311 ("validity for him [viz., for Hart] indicates just membership in a system established in a certain way. It has little to do with binding normative force").

45 J. Raz, 'The Identity of Legal Systems', 93; N. MacCormick, H. L. A. Hart, 21, 110. 
along with other functions such as the one of imposing on officials a duty to apply valid law discussed in (a) and (b) above, is that of a 'closure rule', meaning that it requires officials to apply only the law it validates. This is somewhat justified also by some statements by Hart, who links the rule of recognition to the idea of a legal system ${ }^{46}$, i.e. the idea of a closed, discrete set of norms.

This interpretation has the defect of turning a contingent feature of legal systems into a necessary truth, by encapsulating it into the definition of rule of recognition. Indeed it is entirely contingent, I submit, that a legal system is closed in the relevant sense, i.e. in the sense that its law-applying institutions are forbidden to rely on every non-legal or extra-systemic consideration in discharging their functions. A legal system that happens to allow such a possibility does not shed its quality of being a system. Moreover, as a matter of observable fact, many contemporary legal systems routinely allow judges to resort also to extra-legal or extra-systemic considerations. ${ }^{47}$

So this cannot be considered as a necessary, conceptual defining feature of the rule of recognition.

(d) The rule of recognition as a power-conferring rule. ${ }^{48}$ This interpretation seems to be, superficially at least, the closest to Hart's own wording. Indeed, Hart qualifies the rule of recognition as a secondary rule, and qualifies secondary rules as (inter alia) power-conferring rules - the conclusion that the rule of recognition is a power-conferring rule seems then straightforward.

The important point then is to understand what exactly is the content of the legal power conferred by the rule of recognition. Recall that, under any plausible definition, a legal power is the power to change someone's rights, duties, and generally someone's legal status (either by creating, or

46 The Concept of Law, 95.

47 See supra, fns 39-42 and accompanying text.

48 L. L. Fuller, The Morality of Law, 137; R. Dworkin, Law's Empire, 34 (the rule of recognition "assigns to particular people or groups the authority to make law"). 
by modifying, or by erasing some legal norm). So the exercise of a legal power cannot consist only in an activity of double-checking a list of criteria in order to ascertain, in a purely speculative way, as it were, the validity of a putatively legal norm. The exercise of a legal power must necessarily yield some legal effect. So, if we want to qualify the rule of recognition as a power-conferring rule, we are bound to point at the legal effects that are engendered by the use of the rule of recognition.

In short, then, exactly what kind of power would be granted by the rule of recognition? Is it a power to identify valid law? ${ }^{49}$ It is hard to understand that such a thing can be the object of a legal power, unless one interprets it as a power to constitutively declare what the law is (and so, the law is what courts say it is). This idea has found independent support by some legal theorists, 50 and it also bears at least a grain of truth, but still raises several problems. For one thing, it conflicts with the widespread intuition that courts are law-applying, and not law-creating institution. Moreover, Hart distinguishes between finality and infallibility of judicial decisions, arguing that, unless one is playing the 'game of the scorer's discretion', an authoritative ruling, even a definitive one, might still be legally wrong: it can be final, but it does not change the rules it purports to apply. ${ }^{51}$ In short, if the law is constitutively determined erga omnes by judicial decisions (and this would be so because the rule of recognition allegedly confers the legal power to declare what the law is), this would be tantamount to saying that the rule of recognition is a rule that authorizes the making of new law, and therefore it would rather be a rule of

49 Sometimes Hart seems to express himself in this way. See The Concept of Law, 95 (the rule of recognition is "a rule for conclusive identification of the primary rules of obligation"), and 97 (on the relation, and the partial overlap, between rule of recognition and rules of adjudication).

50 I am referring here to Kelsen's doctrine of the constitutive character of judicial decisions. See General Theory of Law and State, 135.

51 The Concept of Law, 141-147. See also J. Raz, Practical Reason and Norms, 137-141 (on systems of absolute discretion). 
change. On the other hand, if such constitutive power of the courts is limited to the case at hand, then it seems that we are more properly dealing with a rule of adjudication rather than with a rule of recognition.

On this reading, then, the rule of recognition is either a rule of change directed to the courts (because it empowers the courts to declare the law erga omnes), and so valid law is, a posteriori, what the courts say; or it is a rule of adjudication properly understood, because it empowers the courts to state what the law is with final authority for the case at hand.

A fortiori, if the relevant power is bestowed on law-making institutions properly understood, as opposed to law-applying institutions, then the rule of recognition becomes indistinguishable from the rules of change.

(e) The rule of recognition as a duty-imposing and powerconferring rule. ${ }^{52}$ Under this reading, the rule of recognition is both duty-imposing and power-conferring. It is so because the rule of recognition imposes on officials "obligations to recognize certain sources of law as binding, and it bestows powers on them to engage in authoritative acts of law-identification that can fulfil those obligations". ${ }^{53}$

While I have no (or few) quarrel with the 'duty-imposing' side of this interpretation of the rule of recognition, assigning it also a 'power-conferring' role is problematic. Indeed, also in the light of the discussion sub (d), it is not difficult to see that this interpretation includes in the rule of recognition functions that, on Hart's account, are typically performed by rules of adjudication. Hence, on this reading one of the two conceptual devices elaborated by Hart, the rule of recognition and the rules of adjudication, becomes redundant.

52 M. Kramer, Where Law and Morality Meet, 104-105.

53 Ibidem, 104. 
(f) The rule of recognition as a list of criteria of validity. ${ }^{54}$ Hart repeatedly refers to the rule of recognition as a test, a list of criteria complying with which a norm can be said to be valid;55 as such, the rule of recognition would not amount to a mandatory norm, it would not impose nor require any conduct whatsoever -it is rather a conceptual rule, a definition: it provides the definition of valid law according to a certain legal system.

This is surely an elegant interpretation, and one that is strictly positivistic at that, since it does not endow neither the rule of recognition nor any valid law with the quasipositivistic quality of bindingness; that there is a valid law, that there is a socially practised rule of recognition, are not per se reasons to do what the law requires or to 'play along' the legal game with those who - for whatever reason- already practice it. ${ }^{56}$ Still, the interpretation of the rule of recognition as a systemic test of validity suffers from some fatal flaws. In short, where it is the case, as it is in the normality of developed legal systems, that law-making powers are regulated by (secondary) rules of change, the definition of the various conditions of validity for the norms of the system turns out to be incorporated in those very rules of change: a norm is valid if the relevant procedure has been duly followed by the duly competent institution (and the same goes also for the making of valid private arrangements, such as contracts, wills, and so on).

This point seems to surface at times also in Hart's own account of the rule of recognition. For one thing, Hart explicitly says that 'there is a very close connection' between

54 L. Cohen, 'Critical Notice', 408; E. Bulygin, 'Sobre la regla de reconocimiento'; D. Lyons, Ethics and the Rule of Law, 53; R. Caracciolo, El sistema jurídico. Problemas actuales, 44-54; B. Leiter, 'Legal Realism and Legal Positivism Reconsidered', 66-68; A. Marmor, Positive Law and Objective Values, 1, 22, 32-33; E. Diciotti, 'Regola di riconoscimento e concezione retorica del diritto'; R. Guastini, 'The Basic Norm Revisited'.

55 The Concept of Law, 103, 109, 110.

56 A. Marmor, Positive Law and Objective Values, 22 ("the existence of a social practice, in itself, does not provide anyone with an obligation to engage in the practice. The rules of recognition only define what the practice is"). 
rule of recognition and rules of change, since if in the relevant legal system law-making power is itself regulated by rules of change, then the rule of recognition of that system will 'necessarily' include reference to the operation of such rules. ${ }^{57}$ But quite interestingly, at the various junctures where Hart discusses of law-making powers, powers regulated by rules of change, he consistently relates the exercise of those powers to the concept of validity (i.e. the purported subject matter of the rule of recognition). 58 According to Hart, in the end, a valid rule is nothing more and nothing less than a rule produced in accordance with the relevant rules of change.

As a consequence, a rule of recognition conceived as a list of criteria of validity does not add anything to what can already be achieved using (even only in a cognitive, speculative way, as it were) the relevant rules of change of the system. 59 The rule of recognition becomes redundant -it is a 'needless reduplication' 60 of the rules of change.

At best, such a rule of recognition can provide the jurist with something like a shortcut formulation, a synecdoche of whatever criteria of validity are already in place through the operation of the rules of change.

(g) The rule of recognition as a validating rule. ${ }^{61}$ On this reading, the function of the rule of recognition is to answer the question "what is the reason for the validity of the highest rule of change of the system?".

57 The Concept of Law, 96. See also J. Raz, 'The Identity of Legal Systems', 95 ("all the laws conferring legislative powers [...] determine criteria of validity").

58 The Concept of Law, 31, 68-70, 72, 106, 148.

59 See N. Bobbio, 'Norme secondarie'; N. MacCormick, H. L. A. Hart, 114-115; J. Waldron, 'Who Needs Rules of Recognition?'; S. Perry, 'Where Have All the Powers Gone? Hartian Rules of Recognition, Noncognitivism, and the Constitutional and Jurisprudential Foundations of Law', 307-308; A. Marmor, Philosophy of Law, 49 fn 20 (conceding that a 'criteria-of-validity' definition of the rule of recognition conflates it into a rule of change).

60 Indeed, so Hart epitomized Kelsen's Grundnorm: see The Concept of Law, 293.

61 J. Finnis, 'On Hart's Ways: Law as Reason and as Fact', 44. 
The positive contribution of this way of conceiving of the rule of recognition is that it allows to qualify the constitution as valid law, which seems coherent with the common parlance of jurists; moreover, Hart himself sometimes talks as if the rule of recognition lies somewhat behind the constitution. But in the end this interpretation is not convincing. If 'validation' is taken to mean that the rule of recognition imposes a duty to apply valid $\operatorname{law}^{62}$ (in a somewhat Kelsenian way) ${ }^{63}$, then this way of conceiving it is not distinguishable from stance (a) above. And if validation is taken to mean 'providing a criterion of validity', then it is the same as (f). All the more, this position adds either to (a) or to ( $\mathrm{f}$ ) (or to both, as the case may be) a superfluous additional level -in fact, again a 'needless reduplication'. Indeed, if judges already use the constitution to identify valid law, or if judges already assume the constitution as binding (in short, if judges already accept the constitution, either as a conceptual rule or as a duty-imposing rule), then why on Earth should one suppose the putative existence and acceptance of another rule that directs to the constitution?64 Plainly, it is the constitution that does the job, provided it is accepted and used by the officials in the relevant way. More precisely, (part of) the rule of recognition coincides with those parts of the constitution that are effectively accepted and used by officials in order to identify the law that is susceptible of application. But this does not make the constitution per se the rule of recognition: ${ }^{65}$ it is so only

62 The idea of an implicit rule imposing officials a duty to apply the law seems to be endorsed for instance by S. Shapiro, Legality, 86 ("even thought not explicitly mentioned in the text, it is part of federal constitutional law that judges are under such a duty [viz., a duty to apply the Constitution] because officials accept this mandate from the internal point of view").

63 J. Waldron calls this 'the Grundnorm function': see 'Who Needs Rules of Recognition?', 346-348.

64 See S. Munzer, Legal Validity, 66 and ch III generally; R. Guastini, 'Conoscenza senza accettazione'.

65 Further arguments against the identification between the rule of recognition and the constitution are expounded by Raz, 'On the Authority and Interpretation of Constitutions: Some Preliminaries', 333-334. 
insofar as it is accepted and used by the relevant officials to ascertain applicable law.

This point is explained in a very convincing way by Matthew Kramer, who highlights the difference between the 'foundational' and the 'epiphenomenal' levels of existence of the rule of recognition. 66 The foundational level is the fact that some law-identifying criteria is actually used and accepted in the relevant way. The epiphenomenal level instead obtains when the (foundational) rule of recognition is also explicitly and authoritatively formulated in some text, constitutional or otherwise. So a constitutional provision becomes (part of) the rule of recognition only if it reflects the actual practice of the officials -i.e., only if the relevant officials actually use it in their law-making and law-ascertaining activities. Moreover, while conceptually distinct, the foundational level (i.e. the actual practice of recognition) and the epiphenomenal level (i.e. the codification of that practice) are bound to interact deeply. On the one hand the epiphenomenal level will reflect, albeit not necessarily perfectly, the foundational level: would the codified criteria be too remote from the prevailing official practice of recognition, they probably become dead letter soon. On the other hand, codified criteria of recognition will in turn constrain to some extent the subsequent practices of recognition: official law-making and law-ascertaining practice will easily rely on them as the default option.

An example may help clarify this last point. In many civil law systems there is some explicit provision, sometimes even at the constitutional level, requiring judges to ground their decisions only on statutes passed by the Parliament. ${ }^{67}$ Still, as a matter of observable fact, it is often the case that in such legal systems judges regularly resort, in their law-ascertaining activities, to precedents and decisions from other courts, even in the face of an explicit prohibition

66 See M. Kramer, Where Law and Morality Meet, 110-114.

67 For instance, the Italian constitution includes such a clause: see art. 101 ("I giudici sono soggetti soltanto alla legge"). 
to this effect. 68 There are a number of ways to describe this situation. One is to distinguish between 'validity' and 'efficacy', so that in civil law systems only statutory law enjoys validity (and provides grounds for valid judicial decisions), whereas precedents are only efficacious or applied law (American legal realists used to distinguish 'law in books' and 'law in action' along similar lines). Another possible description is to say that while statutes are mandatory sources, precedents are only 'permissive' sources, sources which courts may rely upon. 69 Still another one is to say that the constitutional clause restricting valid sources to statute only is not practiced as the rule of recognition in that legal system - at best, it has to be supplemented with an implicit rule of recognition according to which also precedents are grounds for judicial decisions. In such cases, then, there is no complete coincidence between the foundational and the epiphenomenal levels of the rule of recognition.

To conclude this point. To assume that the rule of recognition validates the constitution is indeed a 'needless reduplication'. The constitution is not validated by the rule of recognition, rather it is the rule of recognition (or more accurately, the rule of recognition consists in the constitutional clauses that bear upon law-making activities), even if only at the epiphenomenal level. The constitution represents the rule of recognition to the extent that it is actually used in the officials' law-making and law-ascertaining practices - realistically, the written constitution is only part of the rule of recognition, since the criteria it provides are easily supplemented with other, non-stated criteria as well with criteria provided by other sources.

68 A rich comparative analysis is in N. MacCormick, R. Summers (eds.), Interpreting Precedents: A Comparative Study; and also J. Bell, 'Comparing Precedent'.

69 Hart himself seems to embrace such a distinction: see The Concept of Law, 295; see also at 153-154, referring to the possibility that courts manipulate the rule of recognition at its fringes. 
The consequence, plainly, is that the constitution is not itself valid law -indeed, it is neither valid nor invalid. ${ }^{70}$

\section{The Rule of Recognition Revisited}

Let's take stock. The many different interpretations that the concept of a rule of recognition has undergone seem to oscillate between two different defects. On the one hand, the duty-based approaches to the rule of recognition ((a), (b), (c), (e) above) cannot easily explain the fact that the courts are not always under a legal duty to apply valid law - because they can be allowed either to depart from valid law, or to apply non-valid law; so, it is inaccurate ${ }^{71}$ to postulate that the rule of recognition both states the criteria of validity and imposes a duty on judges to apply all and only the norms that comply with such criteria. On the other hand, the power- or definitional-based approaches to the rule of recognition ((d), (f), (g) above) cannot help but conflating the rule of recognition with the rules of change, or even with the rules of adjudication. The first kind of defect makes the rule of recognition an inadequate concept on the explanatory level: there are a few interesting things under its sway that are left quite unexplained. The second kind of defect makes the rule of recognition a redundant concept: it has no real job to do.

Is there a way to rescue the rule of recognition from these defects? I believe there is, but only insofar as one is prepared to leave aside substantive portions of Hart's original account of the rule of recognition. Under that original account, as we have seen, the rule of recognition is deeply related to -indeed, it is constitutive of - legal validity. On re-

70 This conclusion is indeed endorsed by many positivists: see R. Guastini, 'Sur la validité de la constitution du point de vue du positivisme juridique' and 'On Legal Order: Some Criticism of the Received View'; L. Ferrajoli, Principia Iuris, vol. 1, 892-893.

71 I mean, it is inaccurate as a theoretical explanation of what goes on in adjudication, while it is not necessarily inaccurate as an interpretation of Hart's thought. 
flection, though, it appears quite clear that such a job is entirely performed by a different kind of rules. Validity is not determined by the rule of recognition, but by the rules that regulate the various law-making activities (legislation and so on); and these, even on Hart's account, are rules of change.

So what is the role, if any, of the rule of recognition, once it is severed from legal validity? Here is a possibility. The rule of recognition is an array of normative considerations that generally direct law-applying officials in the identification of the law that they are bound to apply in their institutional competence. A few clarifications are needed here.

First, the directives that compound the rule of recognition need not have the form of an obligation: they can also be permissions ${ }^{72}$ (so, the rule of recognition can still qualify as duty-imposing, but only in quite a broad sense).

Second, the rule of recognition does not necessarily instruct the law-applying institutions to apply only valid law. Indeed, while valid law is normally apt for judicial application, 73 the rule of recognition can also direct judges towards the application of different kind of standards, including moral considerations, foreign law, invalid law, and so on. ${ }^{74}$ In short, the rule of recognition is not a criteria of legal validity, but rather a criteria of legal applicability; 75 it is a tool of legal reasoning rather than a tool of legal dynamics.

Third, in any minimally complex legal system the rule of recognition as here understood will necessarily include a hierarchical ordering of sources of law, as well as a (defeasible)

72 On 'permissive sources', see supra, fn 69 and accompanying text.

73 And in this sense what Hart says about the relation between the rule of recognition and the rules of change is perfectly coherent and non-redundant at all: see The Concept of Law, 96.

74 See supra, fns 39-42 and accompanying text.

75 On the concept of applicability, see W. Waluchow, Inclusive Legal Positivism, ch 3 ('institutional force'); P. Navarro, J. J. Moreso, 'Applicability and Effectiveness of Legal Norms'; P. Navarro, C. Orunesu, J. L. Rodriguez, G. Sucar, 'Applicability of Legal Norms'; G. Pino, Diritti e interpretazione, ch 2, and 'La aplicabilidad de la normas jurídicas'. 
ordering of interpretive methodologies:76 the rule of recognition will include the preference for some interpretive methodology over others, or possibly even a ban on certain interpretive methodologies.

Fourth, the rule of recognition, as here understood, is the key concept structuring the job of law-applying institutions -it directs them in accomplishing their institutional duties, it compounds the reasons judges and officials generally may have to apply the law. As such, it is normally the object of an ethical-political acceptance. Normally, officials adopt a certain rule of recognition because that rule of recognition reflects their fundamental, and sometimes even unstated as the case may be, ideals of political legitimacy. The rule of recognition is a concept compounding the officials' 'legal ideology'. ${ }^{77}$ Officials follow it, they are committed to it normally on moral grounds, because that rule of recognition (as here understood) is coherent, or is as coherent as it can be, with their fundamental assumptions of political legitimacy. ${ }^{78}$ The repeated 'normalcy' qualification introduced above is intended to embrace the not entirely unrealistic case of officials who act on purely self-interested, prudential grounds, as well as that of the conformist ones.

76 Many commentators have suggested that the criteria of validity provided by the rule of recognition should be supplemented with criteria of interpretation: see for instance N. Bobbio, 'Norme primarie e secondarie', 187-188; K. Greenawalt, 'The Rule of Recognition and the Constitution', 31-35; W. Waluchow, Inclusive Legal Positivism, 76 (on "secondary rules of interpretation"); E. Diciotti, 'Regola di riconoscimento e concezione retorica del diritto', 11-16; and compare the concept of meta-interpretation in S. Shapiro, Legality, 304-306 and passim.

77 I use here a concept analogous to that of 'legal' or 'normative ideology' deployed by A. Ross, On Law and Justice, 75-76 (it "consists of directives which do not directly concern the manner in which a legal dispute is to be settled but indicate the way in which a judge shall proceed in order to discover the directive or directives decisive for the question at issue"). A quite similar concept ("il principio fondamentale") is carved out also by U. Scarpelli, Cos'è il positivismo giuridico, ch VII.

78 Cf N. MacCormick, Legal Reasoning and Legal Theory, 63-64, 139-140 ("what must be essential to the 'internal aspect' of the rule of recognition is some conscious commitment to pursuing the political values which are perceived as underpinning it"); J. Raz, 'On the Authority and Interpretation of Constitutions: Some Preliminaries', 334 (the rule of recognition is a normative practice). 
There is no reason to rule out such possibilities nor do they affect the theoretical picture such as it has been drawn here. It is reasonable to assume, anyway, that the bulk of officials adhere to the system on ethical-political grounds. This is meant to be an empirical, realistic assumption, not a necessary conceptual truth of legal systems.

Fifth, what does ensure the unity of a legal system? For sure, while the rule of recognition is the object of ethical-political acceptance (and so to a certain extent each official will try to mould the rule of recognition as closely as possible to his own preferences), it is clear that each official on his own part is not entirely free to choose a rule of recognition whatsoever. Every single official is integrated in an overall institutional structure that is the result of a historical process -as well as of power relations deeply entrenched in the relevant society. So in normal circumstances (i.e., barring the case of the anarchist, of the foreign agent, and so on) each official will either adhere wholeheartedly to the existing legal system, ${ }^{79}$ or will strive for a compromise between his fundamental ideals of political legitimacy and the existing legal order. In other words, he will strive for a compromise between the legal system as he would like it to be, and the legal system as it emerges from the prevailing practice of the other officials. ${ }^{80}$

I take this to be, by and large, also Hart's view on the subject. Albeit usually reluctant to investigate the reasons officials may have for practicing a certain rule of recognition, ${ }^{81}$ Hart eventually conceded that such reasons include

79 This seems to be the paradigmatic instance of what MacCormick calls 'willing acceptance': see H. L. A. Hart, 109. MacCormick further analyses the concept of acceptance of the law in 'The Concept of Law and The Concept of Law', 183-185.

80 For a similar point, see K. Greenawalt, 'The Rule of Recognition and the Constitution', 8-9; J. Waldron, 'Law' and 'Who Needs Rules of Recognition?', 333-334.

81 Hart indeed excludes, obviously enough, that such reasons can qualify as legal reasons; but then he deliberately leaves unexplored the matter of what kind of reasons exactly they might be (granted they are not legal reasons), since he believes that such an enquiry would be outside the scope of analytical, descriptive legal theory: The Concept of Law, 107-108; for a discussion of this point, see J. Dickson, 'Is the Rule of Recognition Really a Conventional Rule?'. 
also the fact that other officials practice a certain rule of recognition. ${ }^{82}$ Now, it is surely true that the fact of an existing practice (legal or otherwise) is not per se a reason to participate in it. ${ }^{83}$ But it is equally true that, if someone wanted to take part in a certain legal practice (because he has some ex ante views on the moral desirability of that practice, or because it allows him to get a nice paycheck, or a desirable social status, and so on), then he'd better play by the existing rules - even also with a view to reinterpreting them, pressing for their reform, and so on. And in this sense it is obviously true, indeed almost trivially true, that among the reasons a judge might have to 'play along' in the legal practice there is also the fact that other relevant actors concur in the same practice. Wouldn't that be so, one would have indeed some difficulty in distinguishing a judge from, say, a science fiction writer.

In the end, then, convergence on by and large the same rule of recognition by various officials will be the result of something like an 'overlapping consensus': officials may well have partly different views on the legitimacy of the existing legal order, but they converge on some fundamental features of the existing practice (for instance, on a set of undisputed sources of law). ${ }^{84}$ Would not such a basic convergence obtain, it would be difficult indeed to talk of an existing legal system.

Accordingly, the rule of recognition is not entirely a datum for those who practice it, but rather it is constantly subject to change, 85 because existing practice is constantly under the pressure of competing ideals of legitimacy among officials. Indeed, one can view some long-standing debates within the judiciary and the legal academia, such as the debate between

82 'Postscript', 255, 267.

83 As A. Marmor is right in emphasising: see Positive Law and Objective Values, 22, 33.

84 This is assumed even by Dworkin, when he refers to the preinterpretive stage' (the raw legal materials on which there is unchallenged widespread consensus): see Law's Empire, 65-67.

85 J. Raz, 'The Identity of Legal Systems', 94. 
'originalist', 'textualist', and 'living-tree' approaches to constitutional interpretation, exactly in this way —as attempts at implementing (and asserting the superiority of) partly different rules of recognitions. They boil down to different ways to identify (part of) the law that has to be applied by courts. ${ }^{86}$ On the whole, the resulting image of the legal system resembles less a pyramid than Neurath's boat.

The rule of recognition, then, far from being a list of criteria of validity, is the range of criteria and considerations that guide the judge in his law-applying functions: it can direct the judge to the application of valid legal norms or, as the case may be, towards the application of some other kind of standard, or even to the application of an extra-legal norm; and it will include also the preference for some interpretive methodology. On the whole, in contemporary, complex legal systems, product of long historical stratification, with multiple sources, and complicated interactions with other normative systems (such as foreign legal systems, international organizations, and so on) it is quite implausible that the rule of recognition resemble anything like a well-structured, axiomatic set of criteria; more likely, as Jeremy Waldron says, it will work as 'an array of (defeasible) normative considerations', 87 that will work more or less in the way of the search for a reflective equilibrium.

Still, this normative 'array' will surely be recognizable, and its operations even predictable, to a certain extent: it will represent the way in which officials conceive of their institutional role, and the way in which they regularly carry it on.

\section{BIBLIOGRAPHY}

AlExAnder, L. and Schauer, F., 'Rules of Recognition, Constitutional Controversies, and the Dizzying De-

86 A similar point is developed by L. Alexander and F. Schauer, 'Rules of Recognition, Constitutional Controversies, and the Dizzying Dependence of Law on Acceptance', 181-187.

87 J. Waldron, 'Who Needs Rules of Recognition?', 339. 
pendence of Law on Acceptance', in ADLER, M. and HIMmA, K. E. (eds.), The Rule of Recognition and the U.S. Constitution, Oxford U. P., Oxford, 2009.

AtienZA, M. and Ruiz Manero J., A Theory of Legal Sentences, Kluwer, Dordrecht, 1997.

Bell, J., 'Comparing Precedent', Cornell Law Review, vol. 82, 1997, 1243-1278.

BoBBIO N., 'Norme primarie e norme secondarie' (1968), in Studi per una teoria generale del diritto, Giappichelli, Torino, 1971.

_- 'Norme secondarie' (1975), in Contributi ad un dizionario giuridico, Giappichelli, Torino.

Bulygin, E., 'Sobre la regla de reconocimiento' (1976), in Alchourrón, C. E. and Bulygin, E., Análisis lógico y Derecho, Centro de Estudios Constitucionales, Madrid, 1991.

CARACCIOLO, R., El sistema jurídico. Problemas actuales, Centro de Estudios Constitucionales, Madrid, 1988.

CElano, B., 'La regola di riconoscimento è una convenzione?', Ragion pratica, 21, 2003.

CoHen, L., 'Critical Notice', Mind, LXXI, 1962.

Coleman, J., 'Authority and Reason', in GeORGe, R. P. (ed. by), The Autonomy of Law. Essays on Legal Positivism, Clarendon Press, Oxford, 1996.

- The Practice of Principle: In Defence of a Pragmatist Approach to Legal Theory, Oxford U. P., Oxford, 2001.

DiciotTi, E., 'Regola di riconoscimento e concezione retorica del diritto', Diritto \& Questioni Pubbliche, 7, 2007.

Dickson, J., 'Is the Rule of Recognition Really a Conventional Rule?', Oxford Journal of Legal Studies, vol. 27, No. 3, 2007.

Dworkin, R., 'The Model of Rules I' (1967), in Taking Rights Seriously, Duckworth, London, 1978. 
—_, Law's Empire, Bellknap, Cambridge (MA), 1986.

FERrajoli, L., Principia Iuris. Teoria del diritto e della democrazia. vol. 1: Teoria del diritto, Laterza, Roma-Bari, 2007.

FinNis, J., 'On Hart's Ways: Law as Reason and as Fact', American Journal of Jurisprudence, 52, 2007.

Fuller, L. L., The Morality of Law, Yale U. P., New Haven, 1964, 1969.

Green, L., The Authority of the State, Clarendon Press, Oxford, 1988.

- 'The Concept of Law Revisited', Michigan Law Review, 94, 1996.

_- 'Positivism and Conventionalism', Canadian Journal of Law and Jurisprudence, XII, 1, 1999.

Greenawalt, K., 'The Rule of Recognition and the Constitution' (1987), in ADLER, M. and Himma, K. E. (eds.), The Rule of Recognition and the U.S. Constitution, Oxford U.P., Oxford, 2009.

GuAstini, R., 'Sur la validité de la constitution du point de vue du positivisme juridique', in TROPER, M. and JAUME, L. (eds.), 1789 et l'invention de la constitution, Bruxelles-Paris, 1994.

, 'Conoscenza senza accettazione', in GiAnFORMAGGIO, L. and JORI, M. (eds.), Scritti per Uberto Scarpelli, Giuffrè, Milano, 1997.

- 'On Legal Order: Some Criticism of the Received View', Ethical Theory and Moral Practice, 2000, vol. 3, Number 3.

- 'The Basic Norm Revisited', paper presented at the conference 'Legal Science and Legal Theory', Oxford, September $8^{\text {th }} 2010$.

HACKER, P. M. S., 'Hart's Philosophy of Law', in HACKER, P. M. S. and RAZ, J. (eds.), Law, Morality, and Society: 
Essays in Honour of H. L. A. Hart, Clarendon Press, Oxford, 1977.

HART, H. L. A., 'Positivism and the Separation of Law and Morals' (1958), in Essays in Jurisprudence and Philosophy, Clarendon Press, Oxford, 1983.

- The Concept of Law, Clarendon, Oxford, 1961, 1994.

- 'Lon L. Fuller: The Morality of Law' (1965), in Essays in Jurisprudence and Philosophy, Clarendon Press, Oxford, 1983.

- 'Kelsen's Doctrine of the Unity of Law' (1968), in Essays in Jurisprudence and Philosophy, Clarendon Press, Oxford, 1983.

- , 'Postscript', in The Concept of Law, Clarendon, Oxford, 1994.

Himma, K. E., 'Making Sense of Constitutional Disagreement: Legal Positivism, the Bill of Rights, and the Conventional Rule of Recognition in the United States', Journal of Law and Society, 4, 2003.

KELSEn, H., General Theory of Law and State, Harvard U. P., Cambridge (MA), 1945.

KRAMER, M., Where Law and Morality Meet, Oxford U. P., Oxford, 2004.

Lagerspetz, E., The Opposite Mirrors: An Essay on the Conventionalist Theory of Institutions, Kluwer, Dordrecht, 1995.

LEITER, B., 'Legal Realism and Legal Positivism Reconsidered' (2001), in Naturalizing Jurisprudence: Essays on American Legal Realism and Naturalism in Legal Philosophy, Oxford U. P., Oxford, 2007.

LYONS, D., Ethics and the Rule of Law, Cambridge U. P., Cambridge, 1984.

MACCORMiCK, N., Legal Reasoning and Legal Theory, Oxford U. P., Oxford, 1978, 1994. 
—, H. L. A. Hart, Edward Arnold, London, 1981.

- 'A Moralistic Case for A-Moralistic Law', Valparaiso Law Review, vol. 20, 1, 1985.

- 'The Concept of Law and The Concept of Law', in GEORGE, R. P. (ed. by), The Autonomy of Law. Essays on Legal Positivism, Clarendon Press, Oxford, 1996.

- and Summers, R. (eds.), Interpreting Precedents: A Comparative Study, Dartmouth, Aldershot, 1997.

MArmor, A., Positive Law and Objective Values, Clarendon Press, Oxford, 2001.

- Philosophy of Law, Princeton U. P., Princeton, 2011.

MoReso, J. J., Legal Indeterminacy and Constitutional Interpretation, Kluwer, Dordrecht, 1998.

Munzer, S., Legal Validity, Martinus Nijhoff, The Hague, 1972.

NAVARRo P. and Moreso J. J., 'Applicability and Effectiveness of Legal Norms', Law and Philosophy 16, 1997.

NAVARRO, P. et al., 'Applicability of Legal Norms', Canadian journal of law and jurisprudence, 2004, 2.

PERRY, S., 'Where Have All the Powers Gone? Hartian Rules of Recognition, Noncognitivism, and the Constitutional and Jurisprudential Foundations of Law', in ADLER, M. and HimmA, K. E. (eds.), The Rule of Recognition and the U.S. Constitution, Oxford U. P., Oxford, 2009.

PINO, G., 'Norme e gerarchie normative', Analisi e diritto, 2008.

, Diritti e interpretazione. Il ragionamento giuridico nello Stato costituzionale, il Mulino, Bologna, 2010.

_ , 'La aplicabilidad de la norms jurídicas', forthcoming 2012. 
Postema, G., 'Coordination and Convention at the Foundations of Law', Journal of Legal Studies, vol. 11, No. 1, 1982.

RAZ, J., The Concept of a Legal System, Clarendon Press, Oxford, 1970, 1980².

'The Identity of Legal Systems' (1971), in The Authority of Law, Oxford U.P., Oxford, 1979, 2009.

- , Practical Reason and Norms, Oxford U. P., Oxford, 1975, 1990.

- 'The Functions of Law' (1973), in The Authority of Law, Oxford U. P., Oxford, 1979, 2009.

- 'Legal Positivism and the Sources of Law' in The Authority of Law, Oxford U. P., Oxford, 1979, 2009.

- 'The Purity of the Pure Theory' (1981), in The Authority of Law, Oxford U. P., Oxford, 1979, 2009.

- 'Authority, Law, and Morality' (1985), in Ethics in the Public Domain. Essays in the Morality of Law and Politics, Oxford U. P., Oxford, 1994.

- 'On the Authority and Interpretation of Constitutions: Some Preliminaries' (1998), in Between Authority and Interpretation, Oxford U. P., Oxford, 2009.

Ross, A., On Law and Justice, London, Stevens, 1958.

, 'Validity and the Conflict between Legal Positivism and Natural Law' (1961), in Normativity and Norms: Critical Perspectives on Kelsenian Themes, edited by S. PAUlSON, B. Litschewski Paulson, OUP, 1999.

SCARPELli, U., Cos'è il positivismo giuridico, edizioni di Comunità, Milano, 1965.

Schiavello, A., Perché obbedire al diritto? La svolta convenzionalista e i suoi limiti, ETS, Pisa, 2010.

SHAPIRO, S., 'On Hart's Way Out', Legal Theory, 4, 1998.

- 'Law, Plans, and Practical Reason', Legal Theory, 8, 2002. 
- 'What Is the Rule of Recognition (and Does It Exists)?', in ADLER, M. and HIMMA, K. E. (eds.), The Rule of Recognition and the U.S. Constitution, Oxford U. P., Oxford, 2009.

—, Legality, Bellknap Press, Cambridge (MA), 2011.

STAVROPULOS, N., 'Interpretivist Theories of Law', in ZALTA Edward N. (ed.), The Stanford Encyclopedia of Philosophy, Fall 2008 edn, http://plato.stanford.edu/ar chives/fall2008/entries/law-interpretivist/.

WALDRON, J, 'Normative (or Ethical) Positivism', in COLEMAN, J. (ed.), Hart's Postscript: Essays on the Postscript to The Concept of Law, Oxford U. P., Oxford, 2001.

- 'Law', in Oxford Handbook of Contemporary Philosophy, edited by F. Jackson and M. Smith, Oxford U. P., Oxford, 2005.

- , 'Who Needs Rules of Recognition?', in ADLER, M. and HimmA, K. E. (eds.), The Rule of Recognition and the U.S. Constitution, Oxford U. P., Oxford, 2009.

Waluchow, W., Inclusive Legal Positivism, Oxford U. P., Oxford, 1994.

- 'Four Concepts of Validity', in ADLER, M. and HIMMA, K. E. (eds.), The Rule of Recognition and the U.S. Constitution, Oxford U. P., Oxford, 2009. 